Лікарі-стоматологи мають активно спостерігати за здоров'ям та домашнім доглядом за порожниною рота у жінок на етапі планування вагітності та протягом всього періоду гестації.

\title{
Література:
}

1. Laine M.A. Effect of pregnancy on periodontal and dental health. Acta Odontol Scand. 2002. № 5(60). P. 257-264. doi:10.1080/00016350260248210.

2. Usin M. M., Tabares S. M., Parodi R. J., Sembaj A. Periodontal conditions during the pregnancy associated with periodontal pathogens. J. Investig. Clin. Dent. 2013. № 4. P. 54-59.

3. Anwar Saeed Al-Habib. et al. Changes in Periodontal Health during Various Stages of Pregnancy; An Observational Study. EC Dental Science. 2019. № 8 (18). P. 1734-1737.

4. Massoni R.S.d.S., Aranha A.M.F., Matos F.Z. et al. Correlation of periodontal and microbiological evaluations, with serum levels of estradiol and progesterone, during different trimesters of gestation. Sci Rep. 2019. № 9. P. 11762. https://doi.org/10.1038/s41598-019-48288-w

5. Seraphim A.P.C.G., Chiba F.Y., Pereira R.F., Mattera MS.L.C., Moimaz S.A.S., Sumida D.H. Relationship among periodontal disease, insulin resistance, salivary cortisol and stress levels during pregnancy. Braz Dent J. 2016. № 2(27). P. 123-127.

6. Primal K.S, Esther S.R, Boehm T.K. Periodontal Screening and Recording (PSR) Index Scores Predict Periodontal Diagnosis. J Dent App. 2014. № 1(1). P. 8-12.

DOI https://doi.org/10.30525/978-9934-588-81-5-2.46

\section{THE ROLE OF TELEMEDICINE DURING THE COVID-19 PANDEMIC}

\author{
Kiianytsia V. V. \\ Communications Specialist \\ State Institution «Public Health Center of the Ministry \\ of Health of Ukraine» \\ Kyiv, Ukraine
}

Introduction. As of the morning of September 24, 2020, 188106 cases of COVID-19 were laboratory confirmed in Ukraine and 3757 fatalities were registered. 
In the context of the COVID-19 pandemic, the classical healthcare system is not immediately able to effectively manage large numbers of patients.

The forms and methods of communication used in the public health system depend on the tasks they solve, the target audience.

Telemedicine - a field of medicine, namely a set of actions, technologies and measures used in the provision of medical care, using remote means of communication in the form of electronic messaging [1].

The development of telemedicine in Ukraine is still at an initial level, although the demand for telemedicine services is great.

Methods. The systematic review method and the bibliosemantic method have been applied.

Results. In quarantine areas, most medical facilities have been redesigned to handle COVID-19 patients. The benefit of introducing telemedicine in the context of the COVID-19 pandemic is that remote monitoring could prevent the consequences of inappropriate treatment of patients with chronic diseases, the elderly, a group of people with less mobility who may not have access to the nearest local health facility.

Proper use of social media can make a significant contribution to prevention by effectively educating the public.

Developing a network of doctors could help them discuss special cases, share their evidence-based experiences.

Canceled medical conferences, meetings, and medical university education can be conducted online.

Telemedicine in the context of the COVID-19 pandemic can reduce the burden on the healthcare system and reduce the risk of infection for healthcare workers and patients.

Conclusions. Effective outbreak communication will minimize the damage to a nation's international standing, its economy and its public health infrastructure [2].

Telemedicine provides an advantage during health crises by enabling a quick and effective response.

\section{References:}

1. ПОРЯДОК організації медичної допомоги на первинному, вторинному (спеціалізованому), третинному (високоспеціалізованому) рівнях із застосуванням телемедицини. Наказ МО3 України від 19.10.2015 № 681. Верховна Рада України. [Інтернет]. Доступно: https://zakon.rada.gov.ua/laws/show/z1400-15?lang=uk\#Text

2. Outbreak communication guidelines, WHO, 2005. 